\title{
PENGHILANGAN TINTA PADA KERTAS THERMAL BEKAS : PENGARUH KONSISTENSI DAN KONSENTRASI PENDISPERSI FLOTASI
}

\author{
Sulastri Dewanti, Elisabet Aprilyanti, Taslim \\ Departemen Teknik Kimia, Fakultas Teknik, Universitas Sumatera Utara \\ Jl. Almameter Kampus USU Medan, 20155 Indonesia \\ Email : sulastridewanti@gmail.com
}

\begin{abstract}
Abstrak
Daur ulang kertas bekas merupakan jalan keluar bagi industri kertas dalam mengatasi kelangkaan dan semakin terbatasnya keberadaan sumber bahan baku pulp asli. Kertas termal adalah produk dengan rekayasa tinggi yang dilapisi dengan lapisan sensitif panas yang bereaksi dengan kehadiran panas untuk membuat gambar cetak. Tujuan penelitian ini adalah untuk mengkaji pengaruh konsistensi pulp dan konsentrasi pendispersi terhadap penghilangan tinta pada kertas termal bekas. Penelitian ini meliputi tiga tahap, yaitu perendaman, pulping, dan flotasi. Hasil penelitian dianalisis untuk mengetahui derajat putih berdasarkan TAPPI dan uji tarik berdasarkan ASTM. Kondisi terbaik yang diperoleh adalah pada konsistensi pulp 0,8\%, konsentrasi pendispersi $1,5 \%$, suhu flotasi $50{ }^{\circ} \mathrm{C}$ dan waktu flotasi 40 menit. Pada kondisi ini derajat putih yang diperoleh sebesar $72,17 \%$ dan ketahanan tarik sebesar $3,7 \mathrm{kN} / \mathrm{m}$.
\end{abstract}

Kata kunci : kertas bekas, kertas termal, penghilangan tinta, metode flotasi

\begin{abstract}
Recycling of wastepaper is a solution for paper industry to overcome the scarcity and the limited presence of the virgin pulp sources. Thermal paper is a highly engineered product coated with a thermal sensitive layer that reacts in the presence of heat to create the printed image. The purpose of this research is to study the effect of pulp consistency and dispersant concentration on the removal of ink in the thermal paper. There are 3 steps in this research which are immersing, pulping and flotation. The results of this research were measured according to TAPPI and SNI to determine the brightness and tensile strength of the recycled paper, respectively. The excellent conditions were obtained at pulp consistency of $0.8 \%$, dispersant concentration of $1.5 \%$, flotation temperature of $50{ }^{\circ} \mathrm{C}$ and flotation time of 40 minutes. In these conditions, the brightness was $72,17 \%$ and tensile strength was $3.7 \mathrm{kN} / \mathrm{m}$.
\end{abstract}

Keywords : wastepaper, thermal paper, ink removal, flotation method

\section{Pendahuluan}

Kertas adalah bahan yang tipis dan rata, yang dihasilkan dengan kompersi serat yang berasal dari pulp yang telah mengalami pekerjaan penggilingan, ditambah beberapa bahan tambahan yang saling menempel dan jalin menjalin [9]. Meningkatnya konsumsi kertas per kapita memang sangat menguntungkan tetapi kemampuan hutan untuk menyediakan bahan baku secara lestari tidak memadai sehingga menyebabkan pengurasan sumber daya hutan. Untuk mengatasi permasalahan ini, maka diperlukan pemanfaatan bahan baku serat selain yang diperoleh dari kayu. Daur ulang kertas bekas merupakan jalan keluar bagi industri kertas dalam mengatasi kelangkaan dan semakin terbatasnya keberadaan sumber bahan baku pulp asli. Di samping memberikan nilai ekonomis terhadap biaya produksi pembuatan kertas dan karton, pemanfaatan serat sekunder ini dapat mengurangi penggunaan kayu, mengurangi pencemaran lingkungan serta menghemat air dan energi [6]

Pada umumnya, metode deinking pada kertas bekas dapat dibagi menjadi 2 bagian, yaitu metode pencucian dan metode flotasi. Metode flotasi menguntungkan dalam hal menyelamatkan sumber alam karena penggunaan air pada metode ini lebih sedikit dibandingkan pada metode pencucian. Metode flotasi juga memberikan hasil pulp dengan derajat putih yang lebih tinggi dibandingkan dengan metode pencucian [19]

Pada penelitian ini digunakan bahan baku kertas termal seperti kertas fax bekas dan kertas administrasi bekas yang biasanya hanya dibuang dan dibakar. Pada penelitian ini proses yang digunakan untuk menghilangkan tinta pada kertas termal adalah flotasi. Sehingga dalam penelitian ini ditekankan kepada bagaimana pengaruh proses flotasi terhadap banyaknya tinta yang hilang dari kertas termal bekas dengan adanya berbagai perlakuan yang berbeda dan pengaruhnya terhadap kekuatan tarik.

\section{Teori}

Kertas termal adalah produk dengan rekayasa tinggi yang dilapisi dengan lapisan sensitif panas yang bereaksi dengan kehadiran panas untuk membuat gambar cetak [3]. Deinking adalah proses sekunder dalam hal menghilangkan kotoran tinta. Deinking adalah salah satu proses penghilangan tinta dan bahan-bahan lain non serat dari kertas bekas. Proses penghilangan tinta dapat dilakukan dengan dua cara yaitu cara pencucian dan penggapungan [8]. 
Pada proses flotasi, tinta dipisahkan dari serat yang mana udara di dorong dengan adanya bahan pembuat gelembung yang lain. Gelembung yang muncul membawa partikel tinta dan dipisahkan dari atas flotasi [13].

Tahap-tahap flotasi antara lain [2] :

Tahap 1: Tumbukan antara partikel tinta atau kotoran lain dengan gelembunggelembung udara

Tahap 2 : Pelekatan antara partikel-partikel tersebut dengan gelembung udara

Tahap 3 : Pemisahan gelembung-gelembung udara yang sudah mengikat kotoran dengan pulp

Faktor penghilangan tinta (deinkability

factor) kertas daur ulang merupakan faktor yang menunjukkan sejauh mana tinta dapat dihilangkan dari kertas bekas dan tingkat residu tinta yang tertinggal dalam kertas bekas [10]. Faktor penghilangan tinta (deinkability factor) ditentukan berdasarkan persamaan berikut [14]:

$$
\text { Def }=\frac{\text { DerajatPutih(DS) }- \text { DerajatPutih(PS) }}{\text { DerajatPutih(US) }- \text { DerajatPutih(PS) }} \times 100 \%
$$

Dimana Def adalah faktor penghilangan tinta (deinkability factor), DS adalah derajat putih pulp kertas tercetak yang di deinking, PS adalah derajat putih pulp kertas tercetak tanpa deinking dan US adalah derajat putih kertas putih yang tidak diprint.

Faktor penghilangan tinta dapat mencapai 0\%-100\%. Faktor penghilangan tinta yang mendekati $100 \%$ menandakan sebuah proses penghilangan tinta yang sempurna, sedangkan faktor penghilangan tinta yang mendekati $0 \%$ menandakan sangat kecilnya proses penghilangan tinta [9].

\section{Metodologi Penelitian}

Bahan baku utama yang digunakan dalam penelitian ini adalah kertas termal. Kertas termal meliputi kertas fax bekas dan kertas administrasi bekas. Bahan baku penunjang yang digunakan dalam penelitian ini, antara lain kalsium hidroksida, natrium silikat, hidrogen peroksida, deterjen, minyak zaitun dan air.

Peralatan yang digunakan dalam penelitian ini meliputi tangki flotasi sebagai peralatan utama dan beberapa peralatan penunjang. Rangkaian peralatan dapat dilihat pada gambar 1.

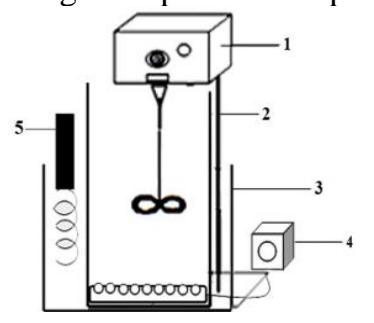

Keterangan :

1. Motor pengaduk dan impeller

2. Tangki flotasi

3. Waterbath

4. Aerator listrik dan penyembur udara

5. Koil pemanas
Proses daur ulang kertas termal bekas meliputi proses perendaman, proses penguraian kertas menjadi serat-serat individu (pulping), proses pelepasan tinta (deinking) dengan metode flotasi, pembuatan lembaran pulp dan analisis pulp. Parameter yang divariasikan merupakan parameter proses flotasi yaitu konsistensi pulp dan konsentrasi pendispersi.

Tahapan prosedur percobaan, kertas termal direndam dengan konsistensi 5\% selama 60 menit. Kemudian setelah direndam ditambahkan kalsium hidroksida 2,5\%, hidrogen peroksida $1,5 \%$ dan natrium silikat 2,5\%. Kemudian dilakukan pengadukan dengan kecepatan $650 \mathrm{rpm}$ pada suhu $50^{\circ} \mathrm{C}$ selama 45 menit. Kemudian dilakukan proses deinking dengan metode flotasi dengan variasi konsistensi, lalu ditambahkan surfaktan dengan variasi konsentrasi dan kolektor $1 \%$. Kemudian dialirkan udara selama 40 menit. Kemudian pulp yang sudah dipisahkan dari tintanya dicetak dan dikeringkan. Kemudian dilakukan analisa derajat putih [16] dan uji tarik [15].

\section{Hasil}

\section{Analisis Derajat Putih}

Analisis yang dilakukan terhadap pulp daur ulang yang dihasilkan meliputi derajat putih dan ketahanan tarik. Derajat putih merupakan suatu metode untuk menentukan derajat putih, mendekati putih, dan berwarna alami dari pulp, kertas, dan karton. Derajat putih adalah istilah industri yang biasa digunakan untuk nilai numerik dari faktor pantul dari sampel terhadap cahaya biru dari spektrum spesifik dan karakteristik geometris. Metode ini membutuhkan instrumen yang memanfaatkan pencahayaan $45^{\circ}$ dan $0^{\circ}$, dimana panjang gelombang yang efektif untuk spektrum adalah $457 \mathrm{~nm}$ [16].

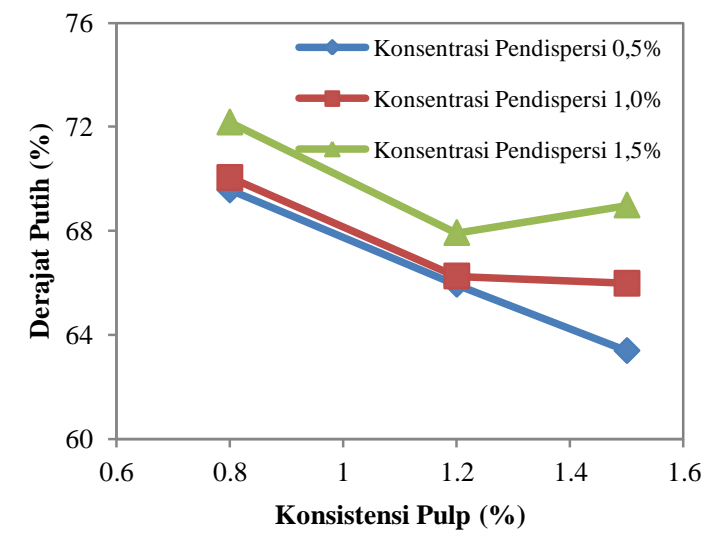

Gambar 2. Pengaruh Konsistensi Pulp terhadap Derajat Putih Kertas pada Kondisi Suhu Flotasi 50 ${ }^{\circ} \mathrm{C}$ dan Waktu Flotasi 40 menit

Gambar 2 menunjukkan pengaruh konsistensi pulp terhadap derajat putih kertas pada kondisi suhu flotasi $50{ }^{\circ} \mathrm{C}$ dan waktu flotasi 40 
menit. Pada gambar 2 dapat dilihat bahwa semakin besar konsistensi pulp maka derajat putih yang dihasilkan semakin menurun. Konsistensi pulp memberikan pengaruh yang nyata pada proses penghilangan tinta. Pada konsistensi yang tinggi, jaringan serat yang kuat dimana menghalangi penghilangan tinta pada jaringan serat lainnya.

Pada keadaan ini jaringan serat dapat menghambat munculnya gelembung udara ke permukaan sehingga mengakibatkan penurunan penghilangan tinta [12]. Pada titik tertentu konsistensi yang bertambah dapat mengakibatkan probabilitas mendestabilisasi gelembung tinta agregat meningkat sehingga menyebabkan efisiensi penghilangan tinta menurun [4].

Pada gambar 2 dapat dilihat bahwa hasil terbaik diperoleh pada konsistensi pulp $0,8 \%$, yaitu $72,17 \%$. Hasil yang diperoleh pada penelitian lebih baik dari yang dilaporkan El-Khalek [11] dimana ia melaporkan hasil terbaik diperoleh pada konsistensi $7 \%$ yaitu $62 \%$ dengan kondisi waktu flotasi 10 menit, temperatur $55^{\circ} \mathrm{C}$ dan 2-oktanol 3\% sebagai surfaktan. Namun ia menggunakan range konsistensi 7\%-15\% dan menggunakan bahan baku kertas bekas perkantoran, dimana hasil derajat putih terendah didapatkan pada konsistensi $15 \%$.

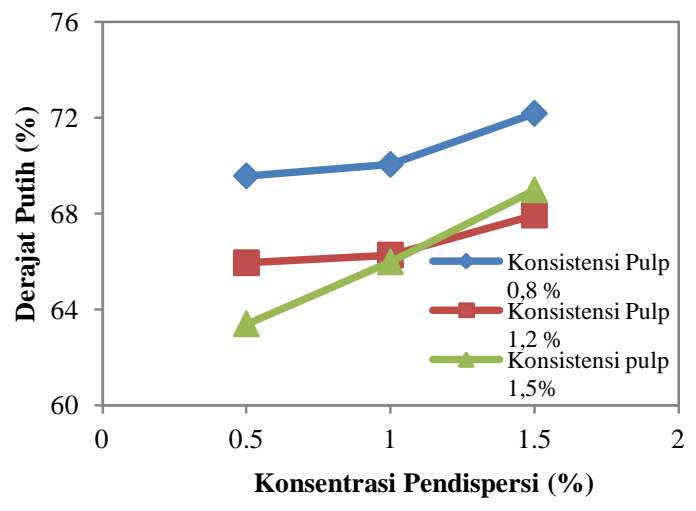

Gambar 3. Pengaruh Konsentrasi Pendispersi terhadap Derajat Putih Kertas pada Kondisi Suhu Flotasi $50{ }^{\circ} \mathrm{C}$ dan Waktu Flotasi 40 menit

Pengaruh konsentrasi pendispersi terhadap derajat putih dapat dilihat pada gambar 3. Pada gambar 3 dapat dilihat bahwa semakin meningkatnya konsentrasi pendispersi flotasi maka derajat putih yang dihasilkan semakin meningkat. Peningkatan konsentrasi pendispersi memberikan efek signifikan pada derajat putih. Dispersan seharusnya membuat permukaan busa stabil untuk penghilangan tinta pada flotasi deinking. Dispersan juga memberikan kelarutan permukaan kimia pada patikel tinta [17]. Dispersan berperan penting dalam pemisahan partikel-partikel tinta dari permukaan serat dan menghindari redeposisi pada pemisahan partikel tinta pada serat selama proses flotasi. Seperti yang diketahui bahwa penambahan surfaktan pada deinking menambah penghilangan tinta sebagai hasil dari penambahan kestabilan busa. Lagi pula penambahan surfaktan pada flotasi mengurangi penghilangan tinta sebagai hasil dari pengurangan hidrophobik dari permukaan partikel tinta yang disebabkan dari adsorpsi surfaktan [18].

Pada gambar 3 dapat dilihat bahwa hasil terbaik diperoleh pada konsentrasi pendispersi $1,5 \%$, yaitu 72,17\%. Zhu,dkk [18] memperoleh hasil terbaik pada konsentrasi pendispersi $0,8 \%$ yaitu derajat putihnya $81 \%$ dengan kondisi konsistensi $0,8 \%$, suhu $40{ }^{\circ} \mathrm{C}$, dan waktu 20 menit. Namun mereka menggunakan range konsentrasi pendispersi dari $0-1 \%$ dan menggunakan bahan baku kertas koran, dimana hasil terendah didapatkan pada konsentrasi pendispersi $0,2 \%$.

\section{Analisis Uji Tarik}

Ketahanan tarik merupakan ukuran ketahanan kertas terhadap tarikan langsung dan dihitung dari beban yang diperlukan untuk menarik putus sebuah jalur dengan dimensi tertentu [5].

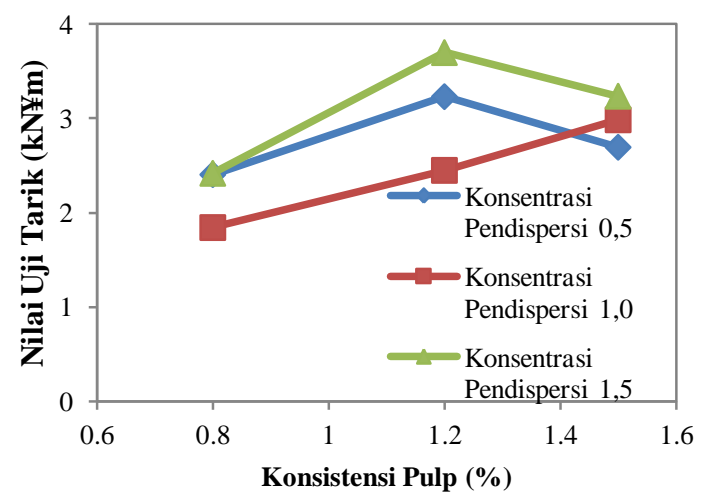

Gambar 4. Pengaruh Konsistensi Pulp terhadap Nilai Uji Tarik Kertas pada Kondisi Suhu Flotasi $50{ }^{\circ} \mathrm{C}$ dan Waktu Flotasi 40 menit

Gambar 4 menunjukkan pengaruh konsistensi pulp terhadap nilai uji tarik kertas, dimana terjadi penurunan pada saat konsentrasi pendispersi $1,5 \%$ dan konsistensi pulp 1,5\%. Hal ini ada kaitannya dengan jumlah noda pada lembaran, semakin rendah kandungan noda pada lembaran maka antar serat tidak terhalang adanya partikel noda akibatnya ikatan antar serat akan lebih baik sehingga ketahanan tarik lembaran meningkat. Sedangkan pada proses pemutihan, bahan kimia pemutih yang digunakan tidak hanya mendegradasi kromofor lignin tetapi bereaksi juga dengan karbohidrat dari selulosa yang menyebabkan ikatan antar serat berkurang, akibatnya ketahanan tarik lembaran turun [5].

Faktor Penghilangan Tinta (Deinkability Factor) Pada penelitian ini, persentase penghilangan tinta terbaik $(68 \%)$ dicapai pada saat konsistensi pulp 0,8\% dan konsentrasi pendispersi 
1,5\%. Faktor penghilangan tinta (deinkability factor) ditentukan berdasarkan pada perbandingan derajat putih kertas daur ulang yang di deinking dengan derajat putih kertas yang tidak di deinking sehingga derajat putih akan selalu berhubungan dengan seberapa banyak tinta yang dapat dihilangkan dari kertas daur ulang [9]. Banyaknya tinta yang dapat dihilangkan memiliki hubungan yang linear dengan derajat putih, dimana semakin banyak tinta yang hilang maka derajat putih akan meningkat juga [20]. Oleh karena itu, pada saat derajat putih tertinggi $(72,17 \%)$ akan menjadi persentase penghilangan tinta terbaik $(68 \%)$.

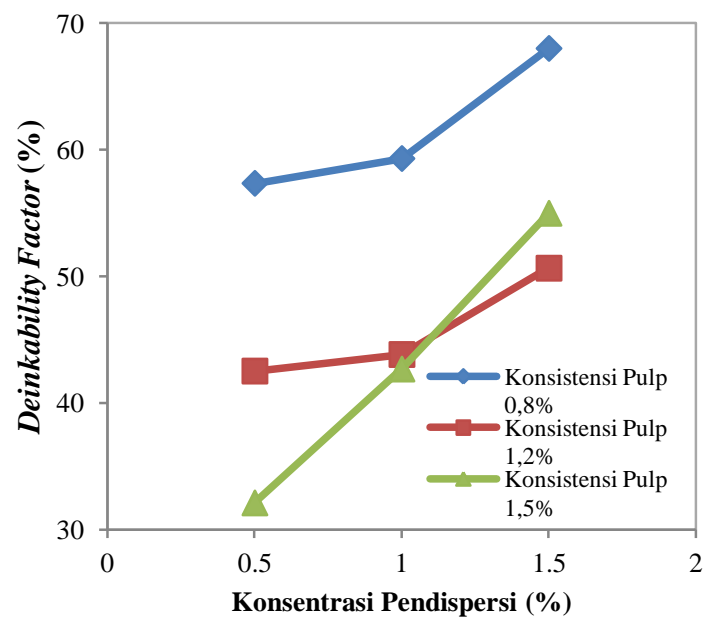

Gambar 5. Pengaruh Konsentrasi Pendispersi terhadap Nilai Def pada Kondisi Waktu Flotasi 40 menit dan Suhu Flotasi $50{ }^{\circ} \mathrm{C}$

Gambar 5 menunjukkan pengaruh konsentrasi pendispersi terhadap nilai Def. Pada gambar 5 dapat dilihat bahwa faktor penghilangan tinta (Def) meningkat dengan semakin besar konsentrasi pendispersi. Hal ini disebabkan pada saat konsentrasi pendispersi $1,5 \%$ derajat putih meningkat karena dispersan berperan penting dalam pemisahan partikel-partikel tinta dari permukaan serat dan menghindari redeposisi pada pemisahan partikel tinta pada serat selama proses flotasi sehingga mengakibatkan kenaikan penghilangan tinta [7].

Gambar 6 menunjukkan pengaruh konsistensi pulp terhadap nilai Def. Pada gambar 6 dapat dilihat bahwa faktor penghilangan tinta (Def) menurun dengan semakin meningkatnya konsistensi pulp. Hal ini disebabkan pada saat konsistensi pulp yang tinggi,derajat putih menurun karena terjadi penumpukan serat sehingga seratnya yang terlalu rapat dapat menghambat munculnya gelembung udara ke permukaan sehingga mengakibatkan kenaikan penghilangan tinta [12].

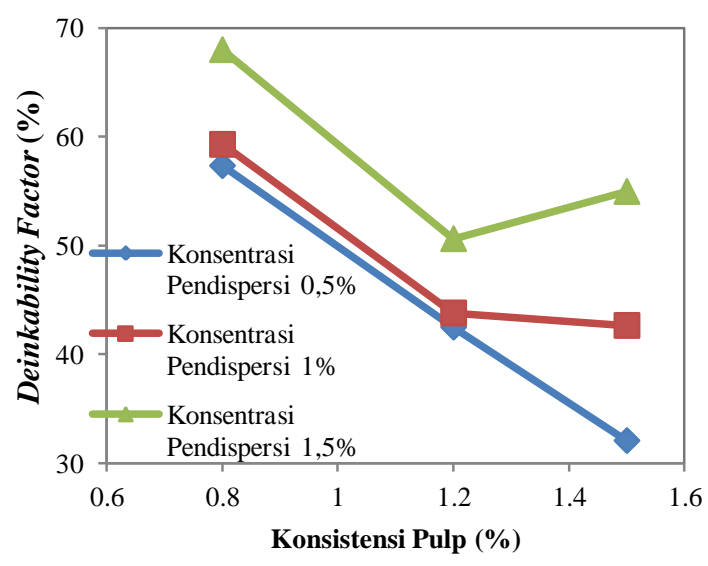

Gambar 6. Pengaruh Konsistensi Pulp terhadap Nilai Def pada Kondisi Waktu Flotasi 40 menit dan Suhu Flotasi $50{ }^{\circ} \mathrm{C}$

Faktor penghilangan tinta dapat mencapai 0\%-100\%. Faktor penghilangan tinta yang mendekati $100 \%$ menandakan sebuah proses penghilangan tinta yang sempurna, sedangkan faktor penghilangan tinta yang mendekati $0 \%$ menandakan sangat kecilnya proses penghilangan tinta [14]. Nilai faktor penghilangan tinta dapat dibagi menjadi 3 grade, yaitu good, fair, dan poor deinkability [1].

\section{Kesimpulan}

Kesimpulan dari penelitian ini adalah :

1. Berdasarkan analisa derajat putih yang dilakukan, semakin besar konsistensi pulp maka derajat putih yang dihasilkan semakin menurun, dengan nilai derajat putih terbesar pada konsistensi pulp $0,8 \%$.

2. Berdasarkan analisa derajat putih yang dilakukan, semakin meningkat konsentrasi pendispersi maka derajat putih yang dihasilkan semakin meningkat, dengan nilai derajat putih terbesar pada konsentrasi pendispersi 1,5\%.

3. Faktor penghilangan tinta menurun dengan meningkatnya konsistensi pulp.

4. Faktor penghilangan tinta meningkat dengan meningkatnya konsentrasi pendispersi.

5. Kertas hasil daur ulang yang paling baik adalah pada konsistensi pulp $0,8 \%$ dan konsentrasi pendispersi $1,5 \%$ dengan derajat putih sebesar $72,17 \%$ dan kekuatan tarik $3,7 \mathrm{kN} / \mathrm{m}$, sesuai dengan spesifikasi tersebut maka kertas hasil .

\section{Daftar Pustaka}

[1] A. Faul, H. J. Putz, "European Deinkability Survey of Printed Products", INGEDE Project 10005 Recyclability Survey, PTS Deinking Symposium, Munich, Deutschland, 2008.

[2] A. Fricker, R. Thompson, A. Manning, "Novel Solutions to New Promblems in Paper 
Deinking”, Pigmen \& Resin Technology, Vol.36, No.2, Hal 141-148, 2007.

[3] EPA, Bisphenol A Alternatives In Thermal Paper, EPA Design for The Environment US, 2012.

[4] Felix Carrasco, Maria Angels Relach, Pere Mutje."Deinking of High-Quality Offset Papers : Influence of Consistency, Agitation Speed, and Air Flow Rate in The Flotation Stage", TAPPI Journal, Vol. 82, No.3, hal. 125-129, 1999.

[5] Jenni Rismijana, Iin naomi Indriani, Tutus Pitriyani, "Penggunaan Enzim SelulaseHemiselulase Pada Proses Deinking Kertas Koran Bekas", Jurnal Matematika dan Sains, 8 (2) : hal 67-71, 2003.

[6] Judy Retti W., M.Verdi Suherman, Paulin Sucipto, Hartono Nyoto, Daur Ulang Kertas HVS Bekas Secara Kimiawi dan Enzimatik, Skripsi, Jurusan Teknik Kimia, Universitas Katolik Parahyangan, Bandung, 2004.

[7] J. Y. Zhu, F. Tan, Y. L. Zhao, "Deinking Selectivity (Z-Factor) : A New Parameter to Evaluate Performance of Flotation Deinking Process." Journal Separation and Purification Technology 43, hal 33-41, 2005.

[8] Kalvin S. Rajagukguk, Pengaruh Umur Kertas dan Penggunaan Bahan Kolektor Terhadap Penghilangan Tinta Kertas Koran Bekas, Skripsi S1, Jurusan Teknologi Industri Pertanian, Institut Pertanian Bogor, Bogor, 1997.

[9] Kasdim Lumbanbatu, Pembuatan dan Karakterisasi Kertas Eceng Gondok, Tesis, Jurusan Fisika, Universitas Sumatera Utara, Medan, 2008.

[10] Luthfi Hakim, "Deinking Enzimatik Pulp Kertas Cetak Laser", Tesis, Ilmu Pengetahuan Kehutanan, Institut Pertanian Bogor, Bogor, 2007.

[11] M. A. Abd. El-Khalek, "Performance of Different Surfactant in Deinking Flotation Process", Elixir International Journal, 46, hal. 8147-8151, 2012.

[12] Mika Korkko, Ossi Laitinen, Sari Vahlroos, Ari Ammala, Jouko Niinimaki, Components Removal In Flotation Deinking, Fibre and Particle Engineering, University of Oulu, Finlandia, 2012.

[13] R.A. Venditti, O. J. Rojas, H. Morris, J. Tucker, K. Spences, C. Austin, L. G. Castillo, Natural Surfactants for Flotation Deinking in Paper Recyling, Department of Pulp and Paper, University of Guadalajara, Mexico, 2012.

[14] Sami Imamoglu, "Deinkability Efficiency of Waste Office Paper Printed Using A
Duplicating Machine", Journal of Applied Sciences, 6 (9) : hal. 2006-2009, 2006.

[15] An American National Standard, Standard Test Method for Tensile Properties of Paper and Paperboard Using Constant-Rate-ofElongation Apparstus, 2002.

[16] TAPPI, TAPPI Test Method Brightness of Pulp, Paper, and Paperboard (Directional Reflectance at $457 \mathrm{~nm}$ ), 2002.

[17] Veronika Husovska. " Investigations of recycled Paper Deinking Mechanism." Dissertations, Doctor of Philosophy, Western Michigan University, hal. 28, 2013.

[18] Yulin Zhao, Yulin Deng, J. Y. Zhu, "Roles of Surfactants in Flotation Deinking", Progress in Paper Recyling, 14 (1) : hal. 41-43, 2004.

[19] Yutaka Okamoto, Yoshie Hirakouchi dan Maasaki Hagiwara, "Deinking Composition for Flotation and Deinking Method", US Patent, No. 5.417.808, US, 1995.

[20] Z. Bolanca, I. Bolanca-Mirkovic, A. Hladnik, Image Analysis and The Characteristics of Deinked Pulp From Digital Prints, (Austria, DAAAM International Scientific Book), Chapter 07, hal 077-086, 2005. 